Филипова А. Г., Еськова А. В.

A. G. Filipova, A. V. Yeskova

СИСТЕМА «СОЦИАЛЬНЫЙ ПОТЕНЦИАЛ ДЕТСТВА В РЕГИОНЕ»: ИСПОЛЬЗОВАНИЕ МЕТОДА «ЧЕРНОГО ЯЩИКА»

\title{
CHILDHOOD SOCIAL POTENTIAL IN THE REGION: «BLACK BOX» METHOD
}

Филипова Александра Геннадьевна - доктор социологических наук, доцент, профессор кафедры социальных наук Дальневосточного федерального университета (Россия, Владивосток); 690950, г. Владивосток, ул. Суханова, 8; 8(914)6517793. E-mail: alexgen77@list.ru.

Ms. Alexandra G. Filipova - Doctor of Sociology, Associate Professor, Professor, Social Sciences Department, Far Eastern Federal University (Russia, Vladivostok); 690950, Vladivostok, Suhanov str., 8, 8(914)6517793. E-mail: alexgen77@list.ru.

Еськова Анна Владимировна - кандидат технических наук, заведующая кафедрой «Информационные системы» Комсомольского-на-Амуре государственного технического университета (Россия, Комсомольскна-Амуре); 681013, г. Комсомольск-на-Амуре, ул. Ленина, 27; 8(909)8995996. E-mail: eskann@yandex.ru.

Ms. Anna V. Yeskova - PhD in Engineering, Head of the Information System Department, Komsomolsk-onAmur State Technical University (Russia, Komsomolsk-on-Amur); 681013, Komsomolsk-on-Amur, Lenin str., 27; 8(909)8995996. E-mail: eskann@yandex.ru.

Аннотация. Выделение элементов системы «Социальный потенциал детства в регионе», описание внешних взаимодействий осуществляются посредством метода «черного ящика». «Черный ящик» предполагает изучение внешних информационных потоков системы при условии неизвестности ее содержания и внутренней структуры. В процессе работы сформирован набор данных для последующего системного анализа: «Входные воздействия на систему»; «Выходные характеристики системы»; «Воздействия внешней среды»; «Ресурсы»; «Внутренние индикаторы системы». Для основательного изучения системы мы прибегаем к ее декомпозиции - выделению разных уровней абстрагирования. На данном этапе исследования изучены «входы» и «выходы» системы, индикаторы приведены к количественному основанию с использованием данных федеральной и региональной статистики. В последующем моделирование системы поможет определить условия достижения агрегированных показателей качества детства в регионе - здоровья, образования и духовно-нравственного развития детей.

Summary. Singling out «Childhood Social Potential in the Region» system elements and description of external interactions are carried out with the help of «a black box» method. "The black box» method includes studying external information streams of the system providing the uncertainty of its contents and internal structure. When studying the data set for the subsequent system analysis has been created. They are «Inlet impacts on the system»; «Outlet characteristics of the system»; «Influences of the external environment»; «Resources»; «Internal indicators of the system». The method of decomposition, allocation of different levels of abstraction in particular is used for thorough study of the system. At the present stage the phases of inlet and outlet have been studied, indicators were normalized to the quantitative basis with use of federal and regional statistics. Thereafter modeling of the system will help define conditions of achievement of the aggregated indicators of the childhood quality in the region health, education and mental and moral development of children.

Ключевые слова: регион, социальный потенциал, детство, системный анализ, метод «черного ящика».

Key words: region, social potential, childhood, system analysis, «the black box» method.

УДК 316.33

Социальный потенциал детства в регионе определяется нами как совокупность ресурсов, резервов и возможностей для детей, проживающих в данном субъекте РФ, в области сохранения здоровья, получения образования и развития духовно-нравственных качеств. 
Система «Социальный потенциал детства в регионе» включает множество объектов, взаимодействующих друг с другом посредством обратных связей, как положительных, так и отрицательных. Для выделения объектов системы, описания внешних взаимодействий системы мы обращаемся к методу «черного ящика». Его использование мы считаем вполне оправданным, поскольку, во-первых, «все реальные объекты фактически являются “черными ящиками”» [3, 159]; во-вторых, метод способствует определению границ «управляющая система (надсистема)» «исследуемая система» как «точки отсчета» для концептуализации предметной области; в-третьих, метод позволяет изучить информационные потоки между «исследуемой системой» - «черным ящиком» и «надсистемой» - «наблюдателем» [3].

В работе «Введение в кибернетику» У. Р. Эшби указывал, что использование методов, соответствующих «черному ящику», приходится применять, когда исследователь «сталкивается с системами, внутренний механизм которых не открыт полностью для наблюдения» [5, 128]. Данные методы заключаются в наблюдении поведения системы на основе измерения входных и выходных воздействий. Однако применение модели «черного ящика» для исследования систем с активными элементами, к которым мы относим систему «Социальный потенциал детства в регионе», накладывает определенные ограничения [3, 563], которые мы предполагаем в дальнейшем снять посредством использования метода «белого ящика».

В результате анализа системы «Социальный потенциал детства в регионе» по методу «черного ящика» построена следующая схема информационных потоков (см. рис. 1).

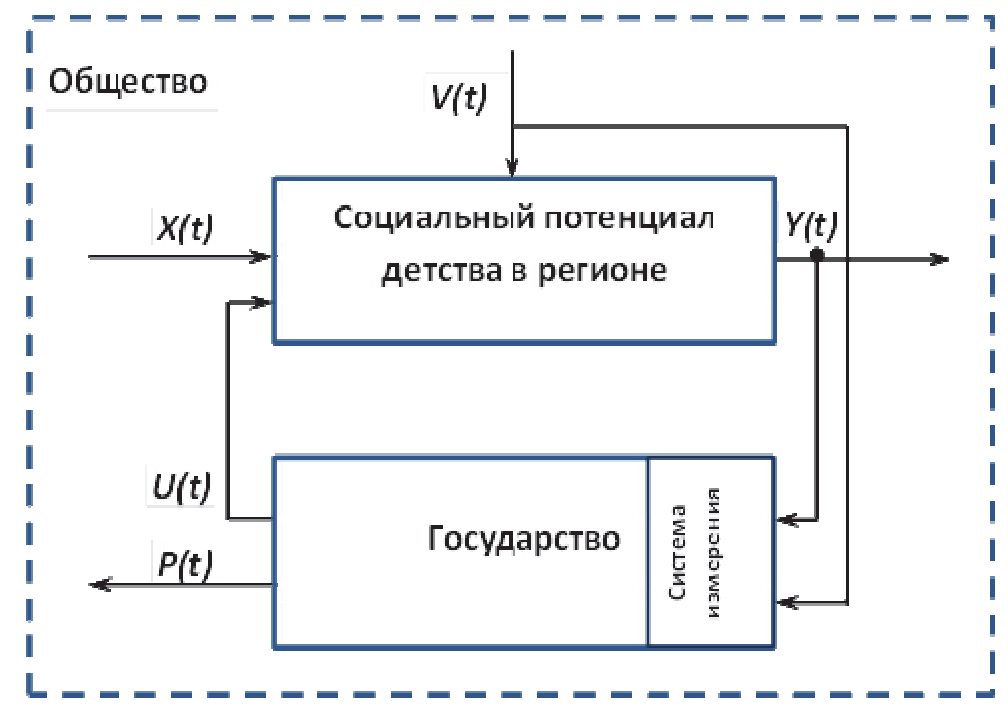

Рис. 1. Информационные потоки в контуре

«система "Социальный потенциал детства в регионе" - надсистемы»

Входные параметры системы «Социальный потенциал детства в регионе» образуют вектор $X(t)=\left(x_{1}(t), x_{2}(t), \ldots, x_{q}(t)\right)$. Выходные параметры системы «Социальный потенциал детства в регионе» образуют вектор состояния $Y(t)=\left(y_{1}(t), y_{2}(t), \ldots, y_{n}(t)\right)$, доступный внешней среде и контролируемый с помощью системы измерений, представляющей собой объекты сбора статистики. Таким образом, вектор $Y(t)=\left(y_{1}(t), y_{2}(t), \ldots, y_{n}(t)\right)$ - это статистические показатели, индикаторы состояния системы в определенный момент времени $t$.

Государственные субъекты управления формируют векторы управляющих сигналов $U(t)=\left(u_{1}(t), u_{2}(t), \ldots, u_{k}(t)\right), \quad P(t)=\left(p_{1}(t), p_{2}(t), \ldots, p_{l}(t)\right) . \quad$ Вектор $\quad U(t)=\left(u_{1}(t), u_{2}(t), \ldots, u_{k}(t)\right) \quad$ обеспечивает компенсационное и корректирующее входное воздействие на систему, замыкая малый круг обратной связи и учитывая значения вектора состояний системы $Y(t)$ и окружающей среды $V(t)$. Так как вектор $U(t)$ по содержанию представляет собой решения законодательной, исполнительно-распорядительной, судебной подсистем государства в области социальной защиты детства, то он воздействует не только на исследуемую систему, но и на общество (окружающую 
среду) в целом. В ответ общество реагирует изменением вектора состояний внешней среды $V(t)=\left(v_{1}(t), v_{2}(t), \ldots, v_{m}(t)\right)$, замыкая большой круг обратной связи. Регулирующие воздействия государства на общество в целом отображает вектор $P(t)$. Эти воздействия реализуются с использованием государственного аппарата принуждения, системы властных предписаний, обязательных для всех жителей страны. Основным государственным документом выступает Конституция РФ, закрепляющая основы конституционного строя, права и свободы человека и гражданина, особенности федеративного устройства и др.

Для описания векторов, характеризующих нашу систему с использованием метода «черного ящика», обратимся к статистическим данным, представленным в университетской информационной системе РОССИЯ (см. прим. 1), статистических сборниках «Дети России 2009» (см. прим. 2) и «Регионы РФ» (см. прим. 3).

Входные параметры системы (вектор $X(t)$ ) определяются обществом, его гендерной, возрастной, брачной и прочими структурами. К индикаторам «входных воздействий» могут быть отнесены: численность населения; возрастная структура населения (коэффициенты демографической нагрузки, распределение численности населения по основным возрастным группам), гендерная структура населения, структура расселения населения (удельный вес городского населения в общей численности населения, удельный вес сельского населения в общей численности населения), брачное состояние населения (соотношение браков и разводов) и др.

Векторы управляющих воздействий $U(t)$ и $P(t)$ имеют разную направленность: в первом случае воздействуют на систему, во втором - на общество в целом. Воздействия государства на детство в регионе принимают форму федеральной социальной политики, продолжающейся в региональной социальной политике. Под социальной политикой в интересах детей понимается «деятельность государства по созданию правовых условий для обеспечения выживания, сохранения и развития детства» [4]. За период с 1990 по 1999 гг. в нашей стране была сформирована правовая база социальных гарантий детства: в области получения образования (Закон № 3266-1 «Об образовании» от 10 июля 1992 г.), материальной поддержки семьи (Федеральный закон № 81Ф3 «О государственных пособиях гражданам, имеющим детей» от 19 мая 1995 г.), социального обслуживания семьей с детьми (Закон № 195-ФЗ «Об основах социального обслуживания населения в РФ» от 10 декабря 1995 г.), поддержки детских общественных инициатив (Федеральный закон № 98-Ф3 «О государственной поддержке молодежных и детских общественных объединений» от 28 июня 1995 г.), профилактики детской безнадзорности и правонарушений (Федеральный закон № 120-Ф3 «Об основах системы профилактики безнадзорности и правонарушений несовершеннолетних» от 24 июня 1999 г.) и др.

Федеральный закон № 124-Ф3 «Об основных гарантиях прав ребенка в РФ» (от 24 июля 1997 г.), систематизировал основные права и гарантии детства. Следующий этап развития социальной политики в интересах детей связан с принятием ряда новых законов: «Об образовании в РФ» (действует с 1 сентября 2013 г.), «Об основах охраны здоровья граждан в РФ» (с 22 ноября 2011 г.), «О защите детей от информации, наносящей вред их здоровью, нравственному и духовному развитию» (с 1 сентября 2012 г.). В соответствии с Национальной стратегией в интересах детей на 2012-2017 гг. Россия приступила к созданию среды, «комфортной и доброжелательной для жизни детей», а «обеспечение благополучного и защищенного детства» объявлено одним из национальных приоритетов страны.

Индикаторами управляющего воздействия государства являются финансирование отраслей социальной сферы детства, формы и размеры социальной поддержки семей с детьми, количество социальных программ поддержки детства и семьи; количество органов, защищающих права детей; количество зафиксированных нарушений прав детей и др.

«Воздействия внешней среды» определяются нами как факторы, слабо поддающиеся управленческому воздействию или поддающиеся воздействию, но в отдаленном будущем. К факторам внешней среды могут быть отнесены: природное богатство (структура и объем полезных ископаемых, в том числе нефти, газа, угля и др., сельско-хозяйственных площадей, площади земель лесного фонда, охотничьих угодий, водных биоресурсов), экология (выбросы 
Филипова А. Г., Еськова А. В.

СИСТЕМА «СОЦИАЛЬНЫЙ ПОТЕНЦИАЛ ДЕТСТВА В РЕГИОНЕ»: ИСПОЛЬЗОВАНИЕ МЕТОДА «ЧЕРНОГО ЯЩИКА»

загрязняющих веществ в атмосферу, сброс сточных вод, природные и техногенные аварии и катастрофы) (см. прим. 4), экономические показатели (уровень жизни населения, величина валового регионального продукта, характеристика финансов и инвестиций), уровень занятости и безработицы населения (характеристика рынка труда и рабочей силы), уровень цен на рынке жилья, динамика цен на потребительском рынке и в производственном секторе, характеристика внешнеэкономической деятельности.

Вектор состояния системы «Социальный потенциал детства в регионе» $Y(t)$ включает три агрегированных выходных показателя - здоровье, образование, духовно-нравственное состояние детства. Содержательное наполнение данных показателей осуществлялось, как и в предыдущих случаях, с привлечением статистических данных.

Интегральный показатель здоровья включает следующие составляющие: количество обращений детей за медицинской помощью; численность вакцинированных детей; распределение детей по группам здоровья; численность детей и подростков, охваченных профилактическими осмотрами, результаты осмотров; заболеваемость детей по основным классам болезней; заболеваемость детей и подростков психическими расстройствами и расстройствами поведения; численность детей с социально обусловленными заболеваниями (алкоголизм и алкогольный психоз, наркомания и токсикомания, ВИЧ-инфекция и СПИД, активный туберкулез, заболевания, передающиеся половым путем); распределение детей с ограниченными возможностями здоровья по причинам инвалидности, формам социального обслуживания (стационарное, на дому и др.).

Интегральный показатель образования включает: охват детей детскими дошкольными учреждениями; численность учащихся общеобразовательных учебных заведений, в том числе занимающихся во вторую и третью смены, в вечерних школах; численность детей вне образования; численность несовершеннолетних, получающих начальное, среднее и высшее профессиональное образование; участие детей в олимпиадах, конкурсах и других мероприятиях межрегионального, общероссийского и международного уровней.

Интегральный показатель духовно-нравственного состояния детства: число выпускаемых детско-юношеских периодических изданий, число изданных книг и брошюр для детей и юношества; число детских библиотек, досуговых учреждений для детей (художественных и музыкальных школ, театральных и танцевальных студий, домов творчества для детей, спортивных клубов, детских бассейнов, стадионов, эколого-биологических учреждений, туристско-краеведческих, технических, военно-патриотических учреждений); количество детских и молодежных общественных организаций; численность несовершеннолетних, совершивших преступные действия (в том числе в состоянии алкогольного и наркотического опьянения); число осужденных несовершеннолетних по видам преступлений; численность несовершеннолетних, состоящих на учете в подразделениях по делам несовершеннолетних; число зарегистрированных преступлений, совершенных в отношении несовершеннолетних.

Метод «черного ящика» помог взглянуть на систему со стороны, определить ее «входы» и «выходы», обозначить воздействия внешней среды. Входные воздействия - это переменные, на которые можно оказывать влияние с целью активизации социального потенциала детства в регионе. Факторы внешней среды мы в некотором смысле воспринимаем как константы, допускающие иногда возможность опосредованного влияния.

Таким образом, мы получили следующий набор данных для системного анализа: «Входные воздействия на систему»; «Выходные характеристики системы»; «Воздействия внешней среды»; «Ресурсы». Агрегированные показатели качества детства в регионе выводят нас на проблему определения внутренних индикаторов системы. Для решения этой задачи мы обратимся в дальнейшем к методу «белого ящика». На следующем уровне декомпозиции - в самой системе «Социальный потенциал детства в регионе» также будет выделена структура управления и получены малые круги обратных связей.

Работа выполнена при финансовой поддержке гранта РФФИ (проект № 16-36-60041). 


\section{ЛИТЕРАТУРА}

1. Винер, Н. Кибернетика, или управление и связь в животном и машине / Н. Винер; пер. с англ. - М.: Сов. Радио, 1958. - 215 с.

2. Кирдина, С. Г. Институциональные матрицы: макросоциологическая объяснительная гипотеза

С. Г. Кирдина // Социологические исследования. - 2001. - № 2. - С. 13-23.

3. Системный анализ и принятие решений: словарь-справочник: учеб. пособие для вузов / под ред.

В. Н. Волковой, В. Н. Козлова. - М.: Высш. шк., 2004. - 616 с.

4. Филипова, А. Г. Детская социальная политика в современной России: от выживания к развитию детства А. Г. Филипова // Ученые записки Комсомольского-на-Амуре государственного технического университета. Науки о человеке, обществе и культуре. - 2015. - № III-2(23). - С. 58-65.

5. Эшби, У. Р. Введение в кибернетику / У. Р. Эшби; пер. с англ. - М.: Изд-во иностранной литературы, 1959. $-432 \mathrm{c}$.

\section{ПРИМЕЧАНИЯ}

1. Университетская информационная система РОССИЯ. Базы данных и on-line анализ. - Режим доступа: http://www.uisrussia.msu.ru/ (дата обращения 02.05.2016).

2. Дети в России. 2009: стат. сб. / ЮНИСЕФ, Росстат. - М.: ИИЦ «Статистика России», 2009. - 121 с.

3. Регионы России. Социально-экономические показатели. 2015: стат. сб. / Росстат. - М., 2015. - 1266 с.

4. ЕM-DAТ Глобальная база природных и техногенных катастроф. - Режим доступа: http://www.emdat.be/ (дата обращения 28.04.2016). 